\title{
COL1A1/PDGFB Fusion Protein
}

National Cancer Institute

\section{Source}

National Cancer Institute. COL1A1/PDGFB Fusion Protein. NCI Thesaurus. Code C99197.

A fusion protein encoded by the COL1A1/PDGFB fusion gene. This protein is comprised

of various portions of the collagen alpha-1(I) chain protein fused to all but the first 21

amino acids of the platelet-derived growth factor subunit B protein. 